\title{
PERUBAHAN ALERGENISITAS PROTEIN KACANG KEDELAI DAN KACANG BOGOR AKIBAT PENGOLAHAN DENGAN PANAS
}

\author{
[Allergenicity Changes of Soybean and \\ Bambara Groundnut Protein Due to Heat Processing]
}

\author{
Nurheni Sri Palupi ${ }^{1,2) \star}$, Sri Rebecca Sitorus ${ }^{3)}$, dan Feri Kusnandar ${ }^{1,2)}$ \\ 1) Departemen IImu dan Teknologi Pangan, Fakultas Teknologi Pertanian, Institut Pertanian Bogor, Bogor \\ 2) SEAFAST Center, Institut Pertanian Bogor, Bogor \\ 3) Badan Ketahanan Pangan, Kementerian Pertanian, Jakarta
}

Diterima 17 Juni 2015 / Disetujui 28 Desember 2015

\begin{abstract}
Legumes contain protein as a potential allergen. Heating process was expected to eliminate the protein allergen. The aim of this study was to assess the changes in molecular weight and allergenicty of soybean grobogan variety and bambara groundnut proteins due to heat processing, i.e. boiling, steaming, oven, and roasting protein isolate was prepared by $\mathrm{pH}$ adjusting. SDS-PAGE method was used to determine the profile of protein molecular weight and the alergenicity was determined by ELISA method. Protein molecular weight profile of grobogan soybean and bambara groundnut that have been boiled, steamed, ovened, and roasted for 30 minutes showed variations when compared to the unheated soybean and bambara groundnut protein isolate. The amount of protein detected was reduced compared with unheated soybean and bambara groundnut. The protein allergens in grobogan soybean had molecular weight 110.0, 98.3, 84.5, 67.4, and 60.2. The heat treatment for 30 minutes removed allergenicity as indicated by no detectable protein band in immunoblotting results and the smaller Optical Density value compared with unheated soybean. Thus, the allergenicity of soybean protein due to heat processing was minimized. Bambara groundnut had protein allergens with molecular weight 113.1, 59.8, and $25.2 \mathrm{kDa}$. Protein allergen with molecular weight 25.2 and $59.8 \mathrm{kDa}$ were detected in bambara groundnut processed through boiling and steaming for 30 minutes, respectively, but ELISA result showed there were still protein allergen of bambara groundnut after the heat treatment for 30 minutes.
\end{abstract}

Keywords: allergy, bambara groundnut, heating process, protein, soybean

\begin{abstract}
ABSTRAK
Kacang-kacangan adalah bahan pangan yang mengandung protein yang berpotensi sebagai alergen. Proses pemanasan diharapkan dapat menghilangkan komponen alergen tersebut. Penelitian ini bertujuan mengetahui perubahan berat molekul protein pada kacang kedelai grobogan dan kacang bogor serta perubahan alergenisitasnya sebagai akibat pengolahan dengan pemanasan, yaitu perebusan, pengukusan, pemanasan oven dan penyangraian. Isolasi protein kacang yang telah dipanaskan menggunakan metode pengaturan $\mathrm{pH}$. Profil berat molekul protein setelah pemanasan dianalisis dengan menggunakan elektroforesis SDS-PAGE, sedangkan pengujian alergenisitas menggunakan uji ELISA. Profil berat molekul protein kacang kedelai grobogan dan kacang bogor yang dipanaskan melalui perebusan, pengukusan, pemanasan oven, dan penyangraian selama 30 menit menunjukkan variasi jika dibandingkan dengan isolat protein kontrol (tanpa pemanasan). Jumlah protein yang terdeteksi pun berkurang dibandingkan dengan isolat protein kontrol. Kacang kedelai grobogan memiliki protein alergen dengan berat molekul 110,0; 98,3; 84,5; 67,4; dan 60,2 kDa, namun proses pemanasan selama 30 menit menghilangkan alergenisitas yang ditunjukkan dengan tidak terdeteksi pita protein alergen pada hasil immunobloting. Nilai optical density (OD) kacang kedelai yang dipanaskan selama 30 menit lebih kecil dibandingkan kontrol kacang kedelai yang tidak dipanaskan. Dengan demikian alerginisitas kacang kedelai dapat diminimalkan dengan proses pemanasan. Kacang bogor memiliki protein alergen dengan berat molekul 113,1; 59,8; dan 25,2 kDa. Setelah proses pemanasan pada kacang bogor, pita protein alergen dengan berat molekul 25,2 kDa masih terdeteksi pada isolat protein dengan perebusan selama 30 menit dan pita protein 59,8 kDa terdeteksi pada pengukusan selama 30 menit, namun uji ELISA menunjukkan bahwa setelah proses pemanasan kacang bogor selama 30 menit masih terdeteksi protein alergen.
\end{abstract}

Kata kunci: alergi, kacang bogor, kacang kedelai, proses pemanasan, protein

*Penulis Korespondensi:

E-mail: hnpalupi@yahoo.com 


\section{PENDAHULUAN}

Sistem imun merupakan pertahanan tubuh yang dimiliki oleh manusia untuk melindungi tubuh dari serangan mikroorganisme, seperti bakteri, virus, dan jamur. Sistem imun dapat memberikan respon yang tergantung dengan kemampuannya dalam mengenali molekul asing, yaitu antigen, dan menghasilkan reaksi untuk menghancurkan antigen tersebut (Kresno, 2001). Pada saat sistem imun melemah, kemampuan melindungi tubuh berkurang sehingga mikroorganisme dapat berkembang di dalam tubuh. Adanya mikroorganisme tersebut menyebabkan sistem imun memberikan respon berlebihan serta tidak terkontrol sehingga menimbulkan reaksi hipersensitivitas yang dapat merusak jaringan dan memicu terjadinya penyakit. Salah satu reaksi hipersensitivitas yang menimbulkan manifestasi klinis yang cukup serius adalah reaksi alergi. Alergi termasuk reaksi hipersensitivitas tipe I dan umumnya merupakan reaksi cepat, karena reaksi terjadi hanya beberapa menit setelah seseorang terpapar oleh alergen yang pada umumnya berupa protein pangan dan dimediasi oleh Imunoglobulin E atau IgE (Sun et al., 2008).

Protein pangan yang bersifat alergen pada seseorang belum tentu berakibat sama terhadap orang lain. Individu yang menunjukkan kecenderungan untuk mengalami alergi disebut individu atopik. Individu atopik memproduksi $\operatorname{lgE}$ lebih banyak sebagai respon terhadap stimulasi antigen tertentu. Pada umumnya protein yang masuk ke dalam tubuh dicerna oleh usus halus menjadi asamasam aminonya. Apabila terdapat pori-pori pada membran sel mukosa usus halus, maka protein yang belum tercerna, termasuk protein alergen, dapat terserap dan dikenali oleh $\lg E$ sebagai protein asing. Reaksi alergi dapat menyebabkan produksi lendir yang berlebih pada hidung, gatal-gatal merah di tubuh, diare, muntah, gangguan saluran nafas, penurunan tekanan darah secara tiba-tiba, bahkan dapat berakibat kematian (Brown, 2004).

Bahan pangan yang dikenal mengandung protein alergen adalah ikan, susu, kacang kedelai, kacang tanah, kerang, telur, gandum, dan udang (Bowman dan Selgrade, 2008). Produk kedelai beserta turunannya banyak digunakan dalam pengolahan pangan karena kandungan nutrisinya yang cukup tinggi, namun kacang kedelai memiliki protein alergen yang dapat berikatan dengan $\lg E$ penderita alergi kedelai. Salah satu kacang kedelai varietas lokal yang memiliki bentuk dan ukuran yang menyerupai kedelai impor adalah kedelai grobogan. Kacang kedelai (Glycine max) mengandung minimal 16 jenis protein yang dapat berikatan dengan $\lg \mathrm{E}$ penderita alergi kedelai. Protein alergen utama pada kedelai adalah Gly m Bd 30K atau P34 dengan berat molekul $30-34 \mathrm{kDa}$, Gly $\mathrm{m}$ Bd $28 \mathrm{~K}$ dengan berat molekul $26 \mathrm{kDa}$, dan Gly m Bd $60 \mathrm{~K}$ dengan berat molekul 63-67 kDa (Ogawa et al., 2000). Selain kacang kedelai, kacang bogor untuk dikembangkan menjadi berbagai pangan olahan sebagai salah satu sumber protein alternatif, namun kacang bogor juga diduga mengandung protein alergen. Astuti (2012) melaporkan bahwa kacang bogor mengandung beberapa protein yang dapat berikatan dengan IgE penderita alergi kacang, yaitu protein dengan berat molekul 30; 42,9; 44,7; 56; 62; 64; dan $69 \mathrm{kDa}$.

Sifat alergenisitas suatu bahan pangan dapat dipengaruhi oleh proses pemanasan, fermentasi, hidrolisis enzimatik, konjugasi dengan karbohidrat, rekayasa genetika dan proses ekstrusi (Wilson et al., 2005). Proses pemanasan dapat menyebabkan denaturasi protein, pembentukan ikatan baru, agregasi, penyusunan ulang ikatan disulfida, maupun modifikasi konformasi lainnya, yang dapat menyebabkan perubahan pada alerginisitas (Mondoulet et al., 2005). Selama proses pengolahan, sifat alergenisitas juga dapat dipengaruhi oleh beberapa faktor seperti waktu penyimpanan, teknik persiapan, proses pemanasan, pencucian, dan interaksi dengan komponen pangan lainnya (Van Putten et al., 2011). Beberapa penelitian telah dilakukan untuk mengetahui pengaruh proses pengolahan terhadap alergenisitas bahan pangan. Proses pemanasan dari protein alergen kacang tanah Ara $\mathrm{h}$ 2/6 pada suhu ekstrim dapat menurunkan kapasitas pengikatan lgE (Vissers et al., 2011). Proses denaturasi dapat merusak epitop konformasi dari protein alergen yang mengakibatkan penurunan pengikatan IgE (Kindt et al., 2007).

Proses pengolahan yang memungkinkan terjadinya reaksi glikosilasi dan glikasi diduga juga berpengaruh pada sifat alergenisitas. Glikosilasi merupakan reaksi pengikatan gugus gula pada gugus lateral asam amino dalam suatu protein secara enzimatis, sedangkan glikasi merupakan reaksi non enzimatis (Wang et al., 2009). Dalam proses pengolahan bahan pangan lebih sering melibatkan reaksi glikasi dibandingkan dengan reaksi glikosilasi, yang terjadi karena adanya ikatan kovalen molekul protein atau lipida dengan molekul gula, seperti fruktosa atau glukosa tanpa adanya aktivitas enzim. Secara tidak langsung derajat glikasi dapat ditunjukkan dengan sifat hidrofobisitas suatu protein yang bereaksi dengan karbohidrat dan turunannya pada kondisi tertentu.

Penelitian ini bertujuan untuk menguji pengaruh proses pemanasan yang umum dilakukan dalam pengolahan pangan (perebusan, pengukusan, penyangraian, dan pengeringan) terhadap berat molekul protein pada kacang kedelai dan kacang bogor serta perubahan alergenisitasnya. Proses pemanasan dapat menyebabkan terjadinya glikasi yang sifat alergenisitas kacang kedelai serta kacang bogor. Dengan mengetahui ada atau tidaknya 
protein alergen pada kacang kedelai dan kacang bogor setelah pengolahan serta potensi alergenitasnya, maka dapat dipilih teknologi pengolahan kacang kedelai dan kacang bogor yang dapat meminimalisasi kejadian alergi akibat mengonsumsinya.

\section{BAHAN DAN METODE}

\section{Bahan}

Kacang kedelai (Glycine max) varietas lokal grobogan yang sudah dikeringkan diperoleh dari Rumah Tempe Indonesia, Bogor sedangkan kacang bogor segar (Vigna subterranea) diperoleh dari pedagang di Pasar Anyar, Bogor. Serum penderita alergi kacang dan bukan penderita alergi diperoleh dari klinik di Bandung. Bahan kimia ANS (1-anilin-8naftalen sulfonat), coomasie brilliant blue G-250 dan substrat DAB (3,3'-diaminobenzidin) berasal dari Sigma-Aldrich. Akrilamid, N,N'-metilen-bisakrilamid berasal dari BIO-RAD. Analisis berat molekul protein dengan SDS-PAGE menggunakan Thermo Scientific Spectra Multicolor Broad Range Protein Ladder yang mengandung 10 protein dengan berat molekul 10-260 kDa. Antibodi sekunder HRP Conjugated Mouse anti-Human IgE diperoleh dari ICL Lab dengan substrat peroksidase TMB (3,3',5,5'-tetrametilbenzidin) berasal dari BIO-RAD.

\section{Proses pemanasan kacang kedelai dan kacang bogor}

Sebelum dipanaskan sampel kacang kedelai dan kacang bogor dianalisis proksimat untuk mengetahui kandungan gizinya. Kacang kedelai dan kacang bogor mentah dipanaskan melalui perebusan, pengukusan, penyangraian dan pengeringan oven masing-masing selama 30 menit. Perebusan dilakukan pada air mendidih dengan perbandingan 1:2 (w/v). Air mendidih juga digunakan pada proses pengukusan selama 30 menit. Pada proses penyangraian, sampel dimasukkan pada wajan yang telah dipanaskan sampai dengan suhu $110^{\circ} \mathrm{C}$ dan kemudian dilakukan pengadukan secara kontinyu selama 30 menit. Pengeringan menggunakan oven dilakukan pada suhu $170^{\circ} \mathrm{C}$. Kacang kedelai dan kacang bogor tanpa pengolahan digunakan sebagai kontrol.

\section{Pengujian hidrofobisitas $\left(\mathrm{H}_{0}\right)$}

Indeks hidrofobisitas diukur dengan metode Alizadeh-Pasdar dan Li-Chan (2000). Seri Isolat protein kacang kedelai dan kacang bogor dibuat dengan konsentrasi $0,005 \%$ sampai $0,025 \%(\mathrm{~g} / \mathrm{mL})$ dalam $10 \mathrm{mM}$ buffer fosfat $(\mathrm{pH}$ 7) dan konsentrasi ANS yang digunakan adalah $8 \mathrm{mM}$ dalam buffer fosfat. Sebanyak $20 \mu \mathrm{L} 8 \mathrm{mM}$ ditambahkan ke dalam $4 \mathrm{~mL}$ larutan protein kemudian didiamkan selama 15 menit dalam ruangan gelap. Intensitas fluoresens dari masing-masing larutan protein diukur dengan spektrometer Ocean Optics USB4000-FL. Indeks hidrofobisitas $\left(\mathrm{H}_{0}\right)$ merupakan nilai slope dari persamaan regresi yang menghubungkan nilai intensitas fluoresensi relatif (IFR) dengan konsentrasi protein (\%).

\section{Isolasi protein}

Kacang kedelai dan kacang bogor yang telah dipanaskan digiling dan diayak dengan ayakan 60 mesh dan kemudian dihitung rendemen tepung yang dihasilkan. Isolasi protein sampel diawali dengan penghilangan lemak (Liu et al., 2007). Sampel yang telah dihaluskan direndam dalam heksana teknis (rasio 1:5 w/v) selama 1 jam pada suhu kamar, kemudian disentrifus (8000 g selama 15 menit pada suhu $4^{\circ} \mathrm{C}$ ). Supernatan yang diperoleh dibuang, sedangkan endapannya diekstrasi kembali sebanyak dua kali untuk menghilangkan kandungan lemak yang masih tersisa. Rendemen isolat protein dihitung berdasarkan berat tepung hasil pemanasan. Isolasi protein menggunakan metode pengaturan $\mathrm{pH}$ (Speroni et al., 2010). Teknik isolasi protein ini diharapkan dapat menghasilkan rendemen yang lebih tinggi dibandingkan teknik lainnya.

Sampel bebas lemak dicampur dengan akuades (rasio 1:10 w/v), kemudian $\mathrm{pH}$ suspensi dinaikkan sampai 8 dengan menggunakan $\mathrm{NaOH} 1$ $\mathrm{N}$ (Merck, Germany), diaduk selama 90 menit pada suhu ruang dan disentrifus $(10,000 \mathrm{~g}$ selama 30 menit pada suhu $4^{\circ} \mathrm{C}$ ). Nilai $\mathrm{pH}$ supernatan yang diperoleh diturunkan sampai 4,5 dengan menggunakan $\mathrm{HCl} 1 \mathrm{~N}$ (Merck, Germany), lalu disentrifus selama 20 menit. Supernatan yang diperoleh dibuang, sedangkan endapan proteinnya diambil dan dikeringkan dengan pengering beku.

\section{Pengujian berat molekul isolat protein}

Elektroforesis SDS-PAGE dilakukan dengan stacking gel $5 \%(\mathrm{pH} 6,8)$ dan separating gel 12\% $(\mathrm{pH} 8,8)$ menggunakan perangkat SDS-PAGE dari BIO-RAD. Proses elektroforesis dilakukan selama 180 menit dengan sumber listrik dijaga konstan pada $70 \mathrm{~V}$ sampai migrasi pewarna tersisa sekitar $0,5 \mathrm{~cm}$ dari dasar. Sebanyak $40 \mu \mathrm{L}$ sampel ditambahkan dengan $10 \mu \mathrm{L}$ buffer sampel. Sampel isolat protein diinjeksikan ke dalam sumur menggunakan mikropipet dan pada salah satu sumur ditempatkan protein ladder. Setelah proses running selesai, dilakukan pewarnaan gel menggunakan coomasie brilliant blue G-250.

\section{Pengujian alergenisitas metode immunobloting}

Gel hasil elektroforesis yang tidak diwarnai ditransfer ke membran nitroselulosa 0,45 $\mu \mathrm{m}$ (BIORAD) untuk proses bloting. Bloting dilakukan selama 1.5 jam pada $90 \mathrm{~V}$. Membran difiksasi dengan 
metanol 50\% lalu diblok dengan menggunakan Bloto. Bloto terdiri dari 5\% susu skim ditambah dengan Phosphate Buffer Saline (PBS) (SigmaAldrich) selama 1 jam pada suhu kamar. Membran dicuci dengan Phospate Buffer Saline-Tween 20 (PBST) 0,05\% (Sigma-Aldrich) sebanyak 3 kali, masing-masing selama 5 menit. Membran ditambahkan serum penderita alergi yang telah diencerkan dua kali dalam Bloto dan diinkubasi selama 1 jam pada suhu kamar. Pencucian dilakukan lagi dengan menggunakan PBST sebanyak tiga kali masingmasing selama 5 menit, kemudian ditambahkan antibodi HRP Conjugated Mouse anti-Human $\lg E$ (pengenceran 1:2000 dalam Bloto) dan diinkubasi selama 1 jam sambil digoyang. Hasil deteksi kompleks protein alergen dengan serum secara kualitatif akan terlihat setelah diberikan substrat DAB, ditandai dengan terjadinya kompleks berwarna coklat pada membran nitroselulosa.

\section{Pengujian alergenisitas metode enzyme linked immunosorbent assay (ELISA)}

Metode ELISA yang digunakan adalah indirect ELISA (Rupa et al., 2008). Sebanyak $100 \mu \mathrm{L} /$ sumur isolat protein sampel $(100 \mu \mathrm{g} / \mathrm{mL})$ yang terlarut dalam bufer karbonat $(0,05 \mathrm{M}, \mathrm{pH} 9,8)$ dilapiskan ke dalam lempeng mikrotiter (Nunc Maxisorb). Inkubasi dilakukan selama 18 jam pada suhu $4^{\circ} \mathrm{C}$, lalu dicuci sebanyak tiga kali dengan PBST (200 $\mu \mathrm{L} /$ sumur). Selanjutnya lempeng mikrotiter diblok dengan larutan Bloto sebanyak $200 \mu \mathrm{L} /$ sumur dan diinkubasi selama 1 jam pada suhu $37^{\circ} \mathrm{C}$. Lempeng mikrotiter kemudian dicuci sebanyak tiga kali dengan PBST (200 $\mathrm{\mu L} /$ sumur). Serum penderita alergi yang telah diencerkan 1:5 dalam Bloto ditambahkan pada lempeng mikrotiter sebanyak $100 \mu \mathrm{L} /$ sumur dan diinkubasi selama 1 jam pada suhu $37^{\circ} \mathrm{C}$. Setelah inkubasi, lempeng mikro-titer dicuci sebanyak tiga kali dengan PBST (200 $\mu \mathrm{L} /$ sumur). Penambahan antibodi sekunder dilaku-kan setelah sebelumnya telah diencerkan 1:6000 dalam Bloto. Antibodi sekunder yang ditambahkan ke dalam lempeng mikrotiter sebanyak $100 \mu \mathrm{L} /$ sumur diinkubasi pada suhu $37^{\circ} \mathrm{C}$ selama 1 jam, dicuci dengan PBST (200 $\mu \mathrm{L}$ /sumur) sebanyak tiga kali, lalu ditambahkan substrat TMB (3,3',5,5'-tetra-metilbenzidin) sebanyak $100 \mu \mathrm{L} /$ sumur, dan diinkubasi lagi selama 20 menit pada suhu $37^{\circ} \mathrm{C}$. Hasil positif ditandai dengan timbulnya warna biru. Reaksi dihentikan dengan menggunakan $\mathrm{H}_{2} \mathrm{SO}_{4} 2 \mathrm{M}$ sebanyak $50 \mu \mathrm{L}$ /sumur dan larutan berubah warna menjadi kuning cerah. Optical Density (OD) diukur dengan menggunakan ELISA reader pada panjang gelombang $450 \mathrm{~nm}$.

\section{HASIL DAN PEMBAHASAN}

\section{Pengolahan kacang kedelai dan kacang bogor}

Hasil analisis proksimat kacang kedelai varietas lokal grobogan dan kacang bogor pada Tabel 1 menunjukkan bahwa kedua kacang tersebut memiliki kandungan protein yang cukup tinggi, yaitu $35,87 \%$ (bk) untuk kacang kedelai dan $22,11 \%$ (bk) untuk kacang bogor. Proses pengolahan kacang kedelai dengan melibatkan pemanasan banyak digunakan dalam pembuatan berbagai produk, seperti tahu, tempe, dan susu kedelai. Selain untuk menginaktivasi antinutrisi seperti trypsin inhibitor, pengolahan dengan panas pada kedelai juga digunakan untuk meningkatkan daya cerna protein, memberikan karakteristik flavor, meningkatkan sifat fungsional protein (pembentukan gel, busa, dan sifat emulsifikasi) serta mengurangi aktivitas alergenisitas produk berbahan dasar kedelai (L'Hocine dan Boye, 2007).

Tabel 1. Hasil analisis proksimat kacang kedelai dan kacang bogor

\begin{tabular}{lcc}
\hline \multirow{2}{*}{ Komposisi } & \multicolumn{2}{c}{$\%(\mathrm{bk})^{*}$} \\
\cline { 2 - 3 } & Kacang Kedelai & Kacang bogor \\
\hline Air & $9,07 \pm 0,06$ & $56,74 \pm 0,05$ \\
Lemak & $22,89 \pm 0,05$ & $11,16 \pm 0,10$ \\
Protein & $35,87 \pm 0,01$ & $22,11 \pm 0,50$ \\
Karbohidrat & $35,63 \pm 0,07$ & $61,68 \pm 0,74$ \\
\hline
\end{tabular}

Keterangan: *Data merupakan nilai rata \pm standar deviasi

Tabel 2 menunjukkan rendeman tepung kacang hasil pemanasan basah (perebusan dan pengukusan) dan pemanasan kering (pemanasan oven dan penyangraian) selama 30 menit. Tepung kacang yang dihasilkan dari pengolahan basah lebih sedikit dibandingkan dengan hasil dari pengolahan kering. Hal ini dapat disebabkan oleh adanya komponen yang terlarut dalam air selama proses perebusan dan pengukusan.

Tabel 2. Rendemen tepung setelah proses pengolahan basah dan kering

\begin{tabular}{lcc}
\hline \multirow{2}{*}{$\begin{array}{c}\text { Proses } \\
\text { Pemanasan }\end{array}$} & \multicolumn{2}{c}{$\%$ Rendemen $(\mathrm{bb})^{\star}$} \\
\cline { 2 - 3 }$(30$ menit) & Kacang Kedelai & Kacang bogor \\
\hline Perebusan & $44,55 \pm 0,78$ & $42,70 \pm 0,99$ \\
Pengukusan & $52,92 \pm 2,72$ & $54,70 \pm 0,99$ \\
Pemanasan oven & $78,06 \pm 0,37$ & $57,46 \pm 1,05$ \\
Penyangraian & $81,3 \pm 1,84$ & $49,96 \pm 0,18$ \\
\hline
\end{tabular}

Keterangan: * Data merupakan nilai rata \pm standar deviasi

\section{Isolat protein kacang}

Sampel kacang kedelai dan kacang bogor yang telah mengalami pemanasan diisolasi proteinnya dengan menggunakan metode pengaturan $\mathrm{pH}$. Teknik isolasi protein ini diharapkan dapat menghasilkan rendemen yang lebih tinggi dibandingkan isolasi protein dengan metode isoelectric precipi- 
tation, aqueous precipitation, dan alcohol precipitations (Wu et al., 2009). Rendemen isolat protein berdasarkan berat tepung kacang dapat dilihat pada Tabel 3. Proses pemanasan dengan air dapat menyebabkan adanya komponen protein yang terlarut dalam air. Selain itu proses pengadukan dalam waktu yang lama pada saat proses isolasi juga dapat menyebabkan adanya komponen protein yang berkurang.

Tabel 3. Rendemen isolat protein (berdasarkan berat tepung kacang)

\begin{tabular}{|c|c|c|}
\hline \multirow[b]{2}{*}{$\begin{array}{c}\text { Proses } \\
\text { Pemanasan }\end{array}$} & \multicolumn{2}{|c|}{$\%$ Rendemen $(\mathrm{bb})^{*}$} \\
\hline & $\begin{array}{l}\text { Kacang } \\
\text { Kedelai } \\
\end{array}$ & $\begin{array}{c}\text { Kacang } \\
\text { bogor }\end{array}$ \\
\hline Perebusan 30 menit & $5,28 \pm 1,66$ & $0,26 \pm 0,04$ \\
\hline Pengukusan 30 menit & $6,38 \pm 0,18$ & $0,22 \pm 0,08$ \\
\hline $\begin{array}{l}\text { Pemanasan oven } \\
30 \text { menit }\end{array}$ & $0,950 \pm 0,001$ & $0,94 \pm 0,20$ \\
\hline $\begin{array}{l}\text { Penyangraian } \\
30 \text { menit }\end{array}$ & $2,15 \pm 0,34$ & $0,26 \pm 0,02$ \\
\hline Tanpa pemanasan & $24,48 \pm 1,45$ & $3,06 \pm 0,08$ \\
\hline
\end{tabular}

Keterangan: *Data merupakan nilai rata \pm standar deviasi

Isolasi protein menggunakan pengaturan $\mathrm{pH}$ dimaksudkan untuk mendapatkan rendemen isolat protein dalam jumlah tinggi, namun pada penelitian ini rendemen isolat protein yang diperoleh setelah proses pemanasan relatif kecil. Secara umum isolat protein kacang kedelai dan kacang bogor diperoleh melalui dua proses utama yaitu ekstraksi dan koagulasi protein. Isolasi dan koagulasi protein sangat dipengaruhi oleh sifat-sifat protein yang terkandung dalam bahan akibat proses pemanasan. Proses pemanasan dapat mengakibatkan terjadinya perubahan $\mathrm{pH}$ titik isoelektriknya $(\mathrm{pl})$ sehingga jenis protein yang dapat terisolasi dapat berubah. Keadaan ini yang menyebabkan rendemen isolat protein yang diperoleh menurun setelah pemanasan. Sebagian besar protein kedelai merupakan kelompok protein globulin yang mempunyai titik isoelektrik 4,1-4,6. Pada umumnya protein globulin akan mengendap pada $\mathrm{pH} 4,1$, sedangkan proteinprotein lainnya seperti albumin dan prolamin bersifat larut dalam air. Penurunan kadar protein selama pemanasan diduga disebabkan terlepasnya ikatan dalam struktur protein yang mengakibatkan terlarutnya komponen protein dalam air. Penurunan rendemen konsentrat protein akibat pemanasan juga ditunjukkan pada hasil ekstraksi protein kacang komak ketika suhu dan waktu ekstraksi ditingkatkan (Purwitasari et al., 2014).

\section{Indeks hidrofobisitas $\left(\mathrm{H}_{0}\right)$}

1-anilin-8-naftalen sulfonat (ANS) merupakan pewarna fluoresen yang banyak digunakan dalam analisis perubahan konformasi protein. ANS akan berkonjugasi dengan grup hidrofobik dari protein yang terekspos ke permukaan akibat adanya pema- nasan. Bagian hidrofobik dari protein yang terekspos ke permukaan memegang peranan penting pada interaksi hidrofobik dan berpengaruh pada sifat emulsi dan pembentukan busa pada pangan yang berasal dari protein (Kato dan Nakai, 1980). Indeks hidrofobisitas $\left(\mathrm{H}_{0}\right)$ dari isolat protein kacang kedelai dan kacang bogor dapat dilihat pada Gambar 1 dan 2.

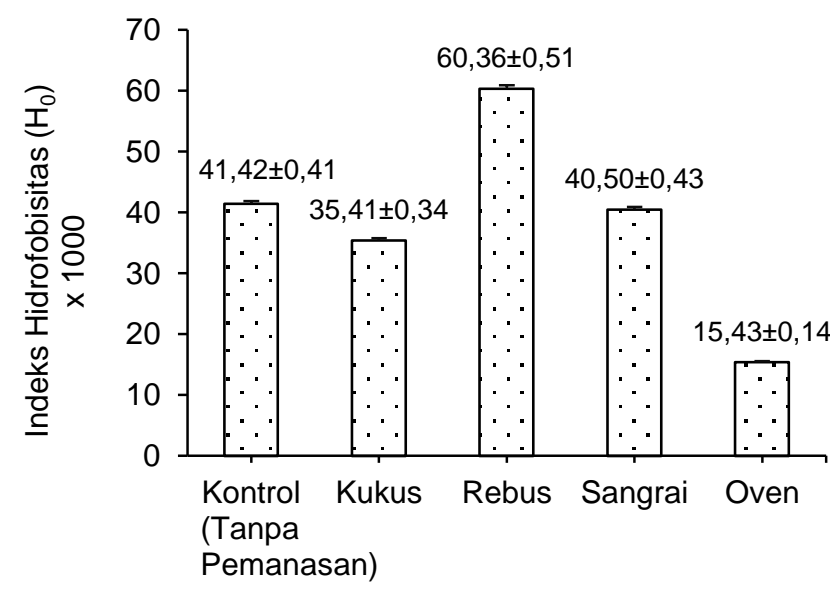

Pemanasan 30 Menit

Gambar 1. Indeks hidrofobisitas $\left(\mathrm{H}_{0}\right)$ kacang kedelai setelah pemanasan selama 30 menit

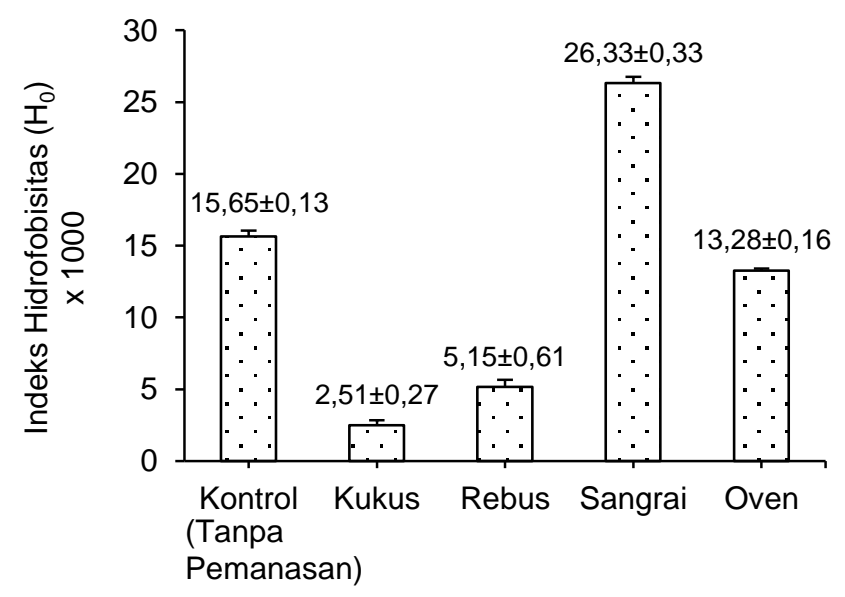

Pemanasan 30 Menit

Gambar 2. Indeks hidrofobisitas $\left(\mathrm{H}_{0}\right)$ kacang bogor setelah pemanasan selama 30 menit

Proses pemanasan mengubah indeks hidrofobisitas isolat protein kacang kedelai dan kacang bogor. Pada sampel isolat protein kacang kedelai (Gambar 1), nilai $H_{0}$ hasil pemanasan lebih rendah daripada $\mathrm{H}_{0}$ isolat protein kacang kedelai kontrol, kecuali pada perebusan selama 30 menit. Sedangkan pada sampel isolat protein kacang bogor (Gambar 2), nilai $\mathrm{H}_{0}$ hasil pemanasan lebih rendah daripada isolat protein kacang bogor kontrol, kecuali pada penyangraian selama 30 menit. Sebagaimana telah dijelaskan sebelumnya, jenis protein dapat terisolasi sangat dipengaruhi oleh sifat protein yang 
dapat berubah akibat pemanasan. Pemanasan dapat mengakibatkan perubahan kelarutan pada $\mathrm{pH}$ titik isoelektriknya ( $\mathrm{pl}$ ) sehingga jenis protein yang terisolasi tidak sama dan berakibat pada terjadinya perubahan hidrofobisias. Hidrofobisitas memiliki peran penting dalam menentukan konformasi protein. Protein yang mengalami denaturasi antara lain dapat dilihat dari perubahan struktur fisiknya. Protein yang terdenaturasi biasanya mengalami pembukaan lipatan pada bagian-bagian tertentu dalam strukturnya. Selain itu, protein yang terdenaturasi akan berkurang kelarutannya. Lapisan molekul yang bersifat hidrofobik akan mengalami perubahan posisi dalam lipatan proteinnya, dari arah dalam ke arah luar, sehingga akan menyebabkan terjadinya perubahan kelarutan. Nilai hidrofobisitas isolat protein kedelai yang dipanaskan lebih tinggi dibandingkan isolat protein tanpa pemanasan (Shen dan Tang, 2012). Xue et al. (2013) melakukan pemanasan kering pada isolat protein kedelai yang dikonjugasikan dengan maltodekstrin dan gum acacia dan diperoleh nilai hidrofobisitas dari isolat protein yang dipanaskan lebih besar daripada isolat protein tanpa pemanasan, namun proses konjugasi dapat menurunkan nilai hidrofobisitas isolat protein kedelai. Hal ini disebabkan proses konjugasi menghambat pengikatan ANS dengan gugus hidrofobik sehingga nilai hidrofobisitas menurun.

\section{Profil berat molekul protein berdasarkan elektro- foresis SDS-PAGE}

Berat molekul fraksi isolat protein dapat diketahui dengan menggunakan elektroforesis SDSPAGE. Analisis ini menggunakan Sodium Dodesil
Sulfat (SDS) yang dapat merusak ikatan non kovalen (seperti ikatan hidrofobik, ionik, dan van der Waals) dan $\beta$-merkaptoetanol yang dapat merusak ikatan disulfida pada rantai polipeptida sehingga protein berada dalam bentuk polipeptida tunggal. Profil berat molekul isolat protein kacang kedelai setelah pemanasan basah dan pemanasan kering dapat dilihat pada Gambar 3A sedangkan profil berat molekul isolat protein kacang bogor dapat dilihat pada Gambar 3B.

Pemanasan kacang menyebabkan profil berat molekul isolat protein bervariasi. Berdasarkan hasil elektroforesis SDS-PAGE, kedelai kontrol (tanpa pemanasan) dengan varietas lokal grobogan memiliki isolat protein dengan berat molekul antara 9,6-114,7 kDa dengan pita protein yang cukup tebal pada berat molekul 54,0 kDa yang termasuk dalam fraksi 7S-globulin dan pita 19,6 kDa yang termasuk dalam fraksi 2S globulin (Ogawa et al., 1991). Pita alergen utama dengan berat molekul 30-34 dan 26 kDa tidak terlihat pada kedelai grobogan. Proses pemanasan basah dan kering menyebabkan profil berat molekul protein kedelai bervariasi dan pada umumnya jumlah protein yang terdeteksi berkurang. Hal tersebut menunjukkan bahwa proses pemanasan menyebabkan terjadinya perubahan kelarutan protein, sehingga mempengaruhi jumlah dan jenis protein yang dapat terekstrak dalam proses isolasi protein. Isolat protein kacang bogor kontrol (tanpa pemanasan) memiliki berat molekul protein 8,5$115,4 \mathrm{kDa}$ dengan pita yang cukup tebal pada berat molekul 71,0; 62,9; dan 25,3 kDa.

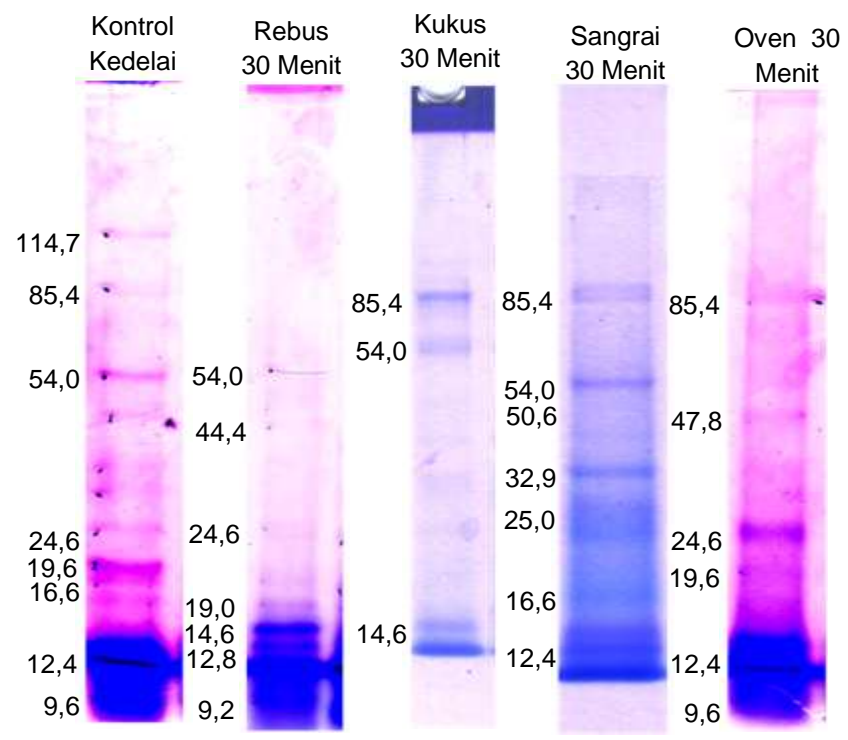

A

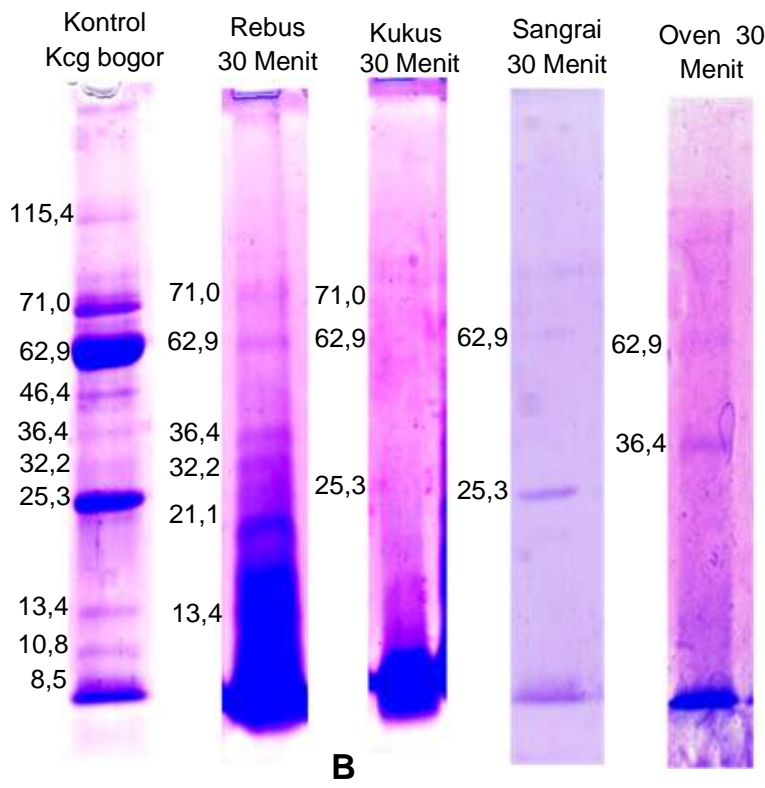

Gambar 3. Profil berat molekul isolat protein kacang kedelai (A) dan kacang bogor (B) setelah pemanasan selama 30 menit 
Astuti (2012) melaporkan hasil elektroforesis SDS-PAGE isolat kacang bogor memiliki profil berat molekul protein 66,$1 ; 63,4 ; 55,7 ; 43 ; 27$; dan 19,2 $\mathrm{kDa}$. Proses pemanasan pada kacang bogor juga menyebabkan profil berat molekul isolat protein kacang bogor bervariasi dan pada umumnya berkurang.

\section{Profil protein alergen berdasarkan pengujian immunobloting}

Alergenisitas isolat protein kacang yang telah mengalami pemanasan dianalisis dengan teknik immunobloting dengan menggunakan serum penderita alergi kacang. Hasil immunobloting isolat protein kacang kedelai dan kacang bogor yang telah mengalami pemanasan basah dan kering selama 30 menit terdapat pada Gambar 4A dan 4B.

Kacang kedelai memiliki alergen utama Gly $m$ $\mathrm{Bd} 30 \mathrm{~K}$ atau disebut juga P34, Gly $\mathrm{m}$ Bd $28 \mathrm{~K}$, dan Gly $\mathrm{m} \mathrm{Bd} 60 \mathrm{~K}$ dengan berat molekul masing-masing 30-34, 26, dan 63-67 kDa (Ogawa et al., 2000). Selain itu terdapat protein alergen lainnya pada kedelai yang dapat berikatan dengan IgE penderita alergi kedelai, yaitu protein dengan berat molekul 26 dan 68 kDa (Astuti, 2012). Pada hasil immunobloting isolat protein kedelai kontrol (tanpa pemanasan), terdapat 5 protein yang dapat berikatan dengan $\mathrm{IgE}$ serum penderita alergi kedelai, yaitu protein dengan berat molekul 110,0; 98,3; 84,5; 67,4; dan 60,2 kDa. Jika dibandingkan dengan hasil elektroforesis SDSPAGE kacang kedelai (Gambar 3A), tidak terlihat pita dari protein-protein tersebut. Hal ini menunjukkan bahwa alergenisitas suatu protein tidak bergantung pada konsentrasi proteinnya. Protein dengan berat molekul 67,4 dan 60,2 kDa termasuk dalam protein utama Gly $\mathrm{m} \mathrm{Bd} 60 \mathrm{~K}$.

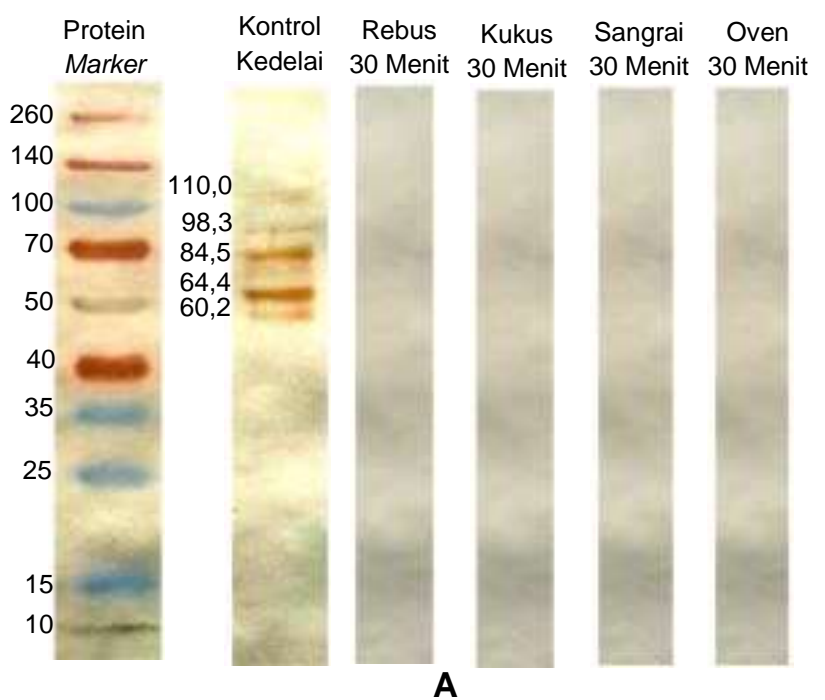

Pada hasil immunobloting isolat protein kacang kedelai yang mengalami perebusan, pengukusan, pemanasan oven, dan penyangraian selama 30 menit, tidak terlihat adanya pita protein yang menunjukkan bahwa tidak ada protein yang berikatan dengan lgE serum penderita alergi. Hal ini menunjukkan bahwa proses perebusan, pengukusan, pemanasan oven, dan penyangraian kacang kedelai selama 30 menit dapat menghilangkan alergenitas isolat protein kedelai grobogan.

Isolat protein kacang bogor tanpa proses pemanasan memiliki protein yang dapat berikatan dengan IgE serum penderita alergi kacang, yaitu protein dengan berat molekul 113,1; 59,8; dan 25,2 kDa (Gambar 4B). Penelitian yang dilakukan Astuti (2012) menunjukkan bahwa kacang kedelai memiliki protein alergen dengan berat molekul $69 ; 64 ; 62 ; 56$; 44,$7 ;$ 42,9; dan $30 \mathrm{kDa}$. Isolat protein kacang bogor yang telah mengalami pemanasan basah masih memperlihatkan pita yang menunjukkan terdapat protein dapat berikatan dengan IgE serum penderita alergi kacang, yaitu protein dengan berat molekul $59,8 \mathrm{kDa}$ pada kacang bogor yang direbus selama 30 menit dan protein dengan berat molekul $25,2 \mathrm{kDa}$ pada kacang bogor yang dikukus selama 30 menit. Perebusan dan pengukusan selama 30 menit belum dapat menghilangkan alergenisitas kacang bogor yang dapat disebabkan karena rendahnya suhu pemanasan maupun waktu pemanasan yang dilakukan hanya selama 30 menit. Namun pada kacang bogor yang telah mengalami pemanasan oven dan penyangraian selama 30 menit tidak terlihat pita protein alergen, yang menunjukkan bahwa proses pemanasan kering dapat menghilangkan alergenisitas isolat protein kacang bogor.

Gambar 4. Profil protein alergen isolat kacang kedelai (A) dan kacang bogor (B) setelah pemanasan 30 menit 
Reaktivitas imunologi isolat protein kacang berdasarkan uji ELISA

Enzyme Linked Immunosorbent Assay (ELISA) digunakan untuk pengujian alergenisitas protein kacang yang telah mengalami pemanasan. Pada pengujian sensitivitas ini, digunakan serum yang berasal dari penderita alergi kacang dan serum dari penderita non alergi sebagai kontrol negatif. Masingmasing serum diikatkan dengan isolat protein kacang dan kemudian dideteksi dengan antibodi sekunder yang berlabel enzim. Nilai Optical Density (OD) pada panjang gelombang $450 \mathrm{~nm}$ protein kacang yang telah mengalami pemanasan terdapat pada Gambar 5 (A) dan (B). Nilai OD yang diperoleh berbanding lurus dengan konsentrasi IgE (Frias et al., 2008).

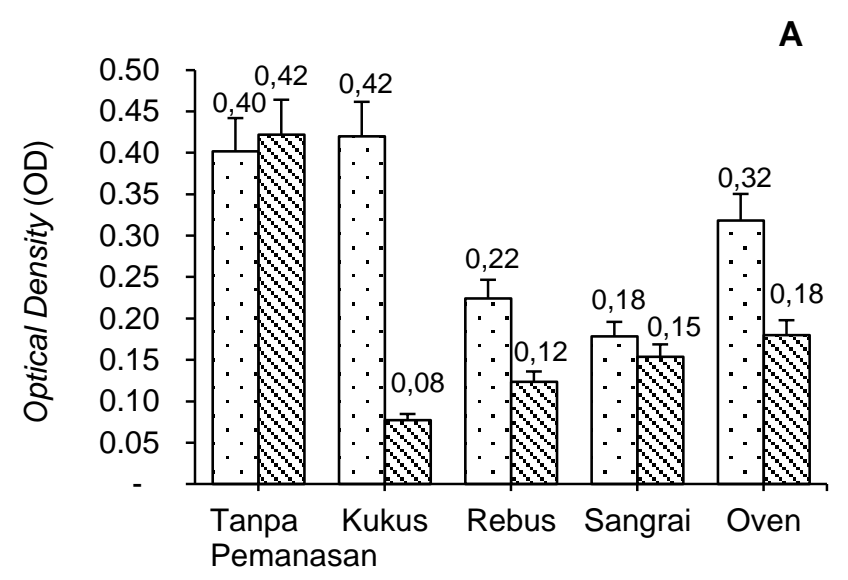

Pemanasan 30 Menit

$\square$ Kontrol negatif $₫$ SlgE kacang kedelai

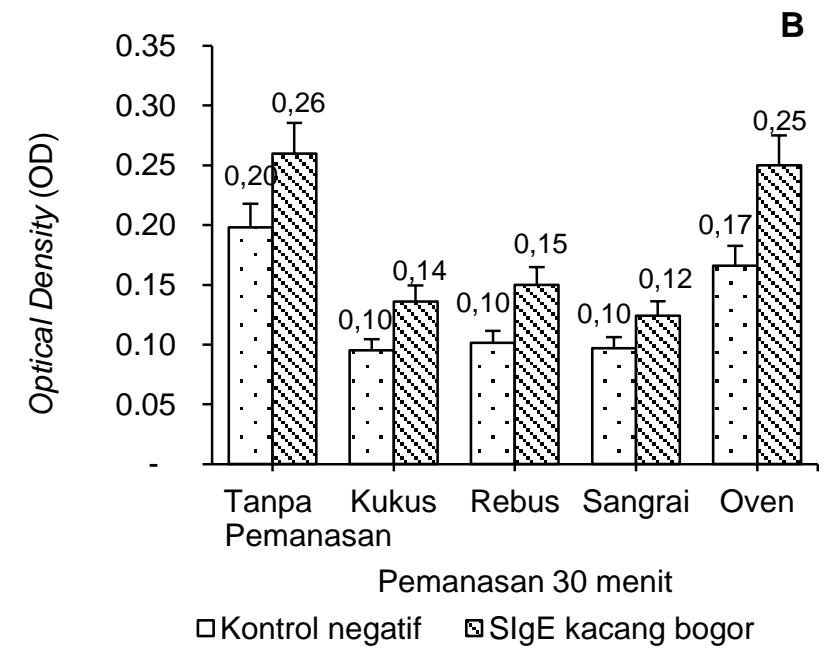

Gambar 5. Reaktivitas imunologi isolat protein kacang kedelai $(A)$ dan kacang bogor $(B)$ setelah pemanasan

Pada hasil uji ELISA isolat protein kacang kedelai (Gambar 5A) dapat dilihat bahwa nilai OD yang lebih tinggi dibandingkan dengan kontrol negatif hanya terdapat pada serum yang berikatan dengan protein kedelai kontrol (tanpa pemanasan). $\mathrm{Hal}$ ini menunjukkan bahwa terdapat protein alergen kedelai yang dapat berikatan dengan IgE serum penderita alergi kacang. Pada isolat protein kedelai yang telah dipanaskan tidak terdeteksi adanya protein alergen yang ditunjukkan dengan nilai $\mathrm{OD}$ yang lebih kecil dari kontrol negatif. Maleki et al. (2000) menunjukkan bahwa protein kacang tanah yang disangrai mengikat IgE lebih tinggi dibandingkan dengan kacang tanah mentah yang disebabkan adanya modifikasi protein akibat reaksi Mailard. Van de Lagemaat et al. (2007) melaporkan bahwa isolat protein kedelai yang terglikasi dengan penambahan fruktosa maupun frukto-oligosakarida melalui reaksi Maillard, menunjukkan adanya penurunan group asam amino primer. Sifat antigenisitas protein terglikasi juga mengalami penurunan sampai dengan $90 \%$ dibandingkan dengan bentuk yang tidak terglikasi.

Hasil uji ELISA isolat protein kacang bogor (Gambar 5B) menunjukkan bahwa semua isolat kacang bogor dengan pemanasan selama 30 menit memiliki nilai OD yang lebih tinggi daripada kontrol negatif. Jika dibandingkan dengan hasil immunobloting isolat protein kacang bogor (Gambar 4B), deteksi positif terdapat pada isolat protein kacang bogor kontrol serta isolat protein kacang bogor dengan perebusan 30 menit dan pengukusan 30 menit. Tidak terdapatnya deteksi positif pada isolat protein kacang bogor dengan pemanasan oven 30 menit dan penyangraian 30 menit dapat disebabkan IgE yang berikatan dengan protein alergen tidak cukup memberikan warna, sehingga hasil immunobloting terlihat negatif.

\section{KESIMPULAN}

Proses perebusan, pengukusan, pemanasan oven, dan penyangraian mempengaruhi profil berat molekul protein isolat kacang. Isolat protein kacang kedelai grobogan tanpa pemanasan memiliki pitapita protein dengan berat molekul 9,6-114,7 kDa, sedangkan kacang bogor memiliki pita protein dengan berat molekul 8,5 kDa sampai 115,4 kDa. Setelah pemanasan selama 30 menit, baik pada isolat protein kacang kedelai maupun kacang bogor, terbentuk protein dengan berat molekul lebih rendah pada masing-masing pengolahan. Kacang kedelai grobogan memiliki protein alergen dengan berat molekul 110,0; 98,3; 84,5; 67,4; dan 60,2 kDa yang dapat berikatan dengan IgE serum penderita alergi kacang, namun proses pemanasan selama 30 menit dapat meminimalisasi alergenisitas yang ditunjukkan dengan tidak terdeteksi pita protein pada hasil immunobloting dan nilai OD setiap pemanasan yang 
lebih kecil daripada kontrol pada hasil ELISA. Kacang bogor memiliki protein alergen dengan berat molekul 113,1; 59,8; dan 25,2 kDa. Setelah proses pemanasan pada kacang bogor, pita protein alergen dengan berat molekul $25.2 \mathrm{kDa}$ terdeteksi pada isolat protein dengan perebusan selama 30 menit dan pita protein 59,8 kDa terdeteksi pada pengukusan selama 30 menit dan tidak terdeteksi pada pemanasan secara kering. Berdasarkan hasil ELISA, masih terdeteksi protein alergen setelah proses pemanasan kacang bogor yang menunjukkan bahwa pemanasan basah dan kering pada kacang bogor selama 30 menit belum mampu menghilangkan alergenisitas kacang bogor.

\section{DAFTAR PUSTAKA}

Alizadeh-Pasdar N, Li-Chan ECY. 2000. Comparison of protein surface hydrophobicity measured at various $\mathrm{pH}$ values using three different fluorescent probes. J Agr Food Chem 48: 328-334. DOI: 10.1021/jf990393p.

Astuti RM. 2012. Isolasi dan Karakterisasi Protein Kacang Kedelai, Kacang Tanah, dan Kacang Bogor untuk Pembuatan Isolat Alergen. [Tesis]. Bogor: Fakultas Teknologi Pertanian, Institut Pertanian Bogor.

Bowman CC, Selgrade MK. 2008. Failure to induce oral tolerance in mice is predictive of dietary allergenic potency among foods with sensitizing capacity. Toxicol Sci 106: 435-443. DOI: 10.1093/toxsci/kfn200.

Brown SGA. 2004. Clinical features and severity grading of anaphylaxis. J Allergy Clin Immun 114: 371-376. DOI: 10.1016/j.jaci.2004.04. 029.

Frias J, Song YS, Martinez-Villaluenga $C$, de Mejia EG, Vidal-Valverde C. 2008. Immunoreactivity and amino acid content of fermented soybean products. J Agr Food Chem 56: 99-105. DOI: 10.1021/jf072177j.

Kato A, Nakai S. 1980. Hydrophobicity determined by a fluorescence probe method and its correlation with surface properties of proteins. Bba-Protein Struct M 624: 13-20. DOI: 10.1016/0005-2795(80)90220-2.

Kindt TJ, Goldsby RA, Osborne BA. 2007. Immunology. New York: Sara Tenney.

Kresno SR. 2001. Imunologi: Diagnosis dan Prosedur Laboratorium. Jakarta: Fakultas Kedokteran Universitas Indonesia.

L'Hocine L, Boye Jl. 2007. Allergenicity of soybean: New developments in identification of allergenic proteins, cross-reactivities and hypoallergenization technologies. Crit Rev Food Sci 47: 127143.
Liu C, Wang H, Cui Z, He X, Wang X, Zeng X, Ma H. 2007. Optimization of extraction and isolation for $11 \mathrm{~S}$ and $7 \mathrm{~S}$ globulins of soybean seed storage protein. Food Chem 102: 1310-1316. DOI: 10.1016/j.foodchem.2006.07.017.

Maleki SJ, Chung SY, Champagne ET, Raufman JP. 2000. The effects of roasting on the allergenic properties of peanut proteins. J Allergy Clin Immun 106: 763-768. DOI: 10.1067/mai.2000. 109620.

Mondoulet L, Paty E, Drumare MF, Ah-Leung S, Scheinmann P, Willemot RM, Wal JM, Bernard $\mathrm{H}$. 2005. Influence of thermal processing on the allergenicity of peanut proteins. J Agric Food Chem 53: 4547-4553. DOI: 10.1021/jf050091p.

Ogawa T, Bando N, Tsuji H, Okajima H, Nishikawa K, Sasaoka K. 1991. Investigation of the IgEbinding proteins in soybeans by immunoblotting with the sera of the soybean-sensitive patients with atopic dermatitis. J Nutr Sci Vitaminol 37: 555-565. DOI: 10.3177/jnsv. 37.555.

Ogawa T, Samoto M, Takahashi K. 2000. Soybean allergens and hypoallergenic soybean products. $J$ Nutr Sci Vitaminol 46: 271-279. DOI: 10.3177/jnsv.46.271.

Purwitasari A, Hendrawan Y, Yualianingsih R. 2014. Pengaruh suhu dan waktu ekstraksi terhadap sifat fisik kimia dalam pembuatan konsentrat protein kacang komak (Lablab purpureus (L.) sweet). J Bioproses Komoditas Tropis 2: 42-53.

Rupa P, Hamilton K, Cirinna M, Wilkie BN. 2008. Porcine IgE in the context of experimental food allergy: Purification and isotype-specific antibodies. Vet Immunol Immunop 125: 303-314. DOI: 10.1016/j.vetimm.2008.05.028.

Speroni F, Milesi V, Anon MC. 2010. Interactions between isoflavones and soybean proteins: Application in soybean protein isolate production. LWT-Food Sci Technol 43: 1265-1270. DOI: 10.1016/j.Iwt.2010.03.011.

Shen L, Tang CH. 2012. Microfluidization as a potential technique to modify surface properties of soy protein isolate. Food Res Int 48: 108118. DOI: 10.1016/j.foodres.2012.03.006.

Sun P, Li D, Li Z, Dong B, Wang F. 2008. Effects of glycinin on $\mathrm{lgE}$-mediatedincrease of mast cell numbers and histamine release in the small intestine. J Nutr Biochem 19: 627-633. DOI: 10.1016/j.jnutbio.2007.08.007.

Van de Lagemaat J, Manuel SJ, Javier MF, Agustin O, Dolores MC. 2007. In vitro glycation and antigenicity of soy proteins. Food Res Int 40: 153-160. DOI: 10.1016/j.foodres.2006.09.006.

Van Putten MC, Kleter GA, Gillisen LJWJ, Gremmen B, Wichers HJ, Frewer LJ. 2011. Novel food 
and allergy: Regulations and risk-benefit assessment. Food Cont 22: 143-157. DOI: 10.1016/j.foodcont.2010.08.002.

Vissers YM, Blanc F, Skov PS, Johnson PE, Rigby NM, Przybylski-Nicaise L, Bernard H, Wal JM, Ballmer-Weber B, Zuidmeer-Jongejan L, Szepfalusi Z, Ruinemans-Koerts Janneke, Jansen APH, Savelkoul HFJ, Wichers HJ, Mackie AR, Mills CEN, Adel-Patient K. 2011. Effect of heating and glycation on the allergenicity of $2 S$ albumins (Ara $h$ 2/6) from peanut. PLoS One 6: e23998. DOI: 10.1371/ journal.pone.0023998.

Wilson S, Blaschek K, de Mejia E. 2005. Allergenic proteins in soybean: Processing and reduction of P34 allergenicity. Nutr Rev 63: 47-58. DOI: 10.1301/nr.2005.feb.47-58.
Wang J, Sun B, Cao Y, Tian Y. 2009. Protein glycation inhibitory activity of wheat bran feruloyl oligosaccharides. Food Chem 112: 350353. DOI: 10.1016/j.foodchem.2008.05.072.

Wu H, Wang Q, Ma T, Ren J. 2009. Comparative studies on the functional properties of various protein concentrate preparations of peanut protein. Food Res Int 42: 343-348. DOI: 10.1016/j.foodres.2008.12.006.

Xue F, Li C, Zhu X, Wang L, Pan S. 2013. Comparative studies on the physicochemical properties of soy protein isolate-maltodextrin and soy protein isolate-gum acacia conjugate prepared through Maillard reaction. Food Res Int 51: 490-495. DOI: 10.1016/j.foodres.2013. 01.012 . 